\title{
GTF2H4 wt Allele
}

National Cancer Institute

\section{Source}

National Cancer Institute. GTF2H4 wt Allele. NCI Thesaurus. Code C89755.

Human GTF2H4 wild-type allele is located in the vicinity of $6 \mathrm{p} 21.3$ and is approximately

$114 \mathrm{~kb}$ in length. This allele, which encodes general transcription factor IIH subunit 4 protein, is involved in the mediation of both gene transcription and DNA repair. 